\title{
Capability of Paraguaçu estuary (Todos os Santos Bay, Brazil) to form oil-SPM aggregates (OSA) and their ecotoxicological effects on pelagic and benthic organisms
}

\author{
Mariana C. Rios a ${ }^{\text {a }}$ Ícaro T.A. Moreira ${ }^{\mathrm{a}, *}$, Olívia M.C. Oliveira ${ }^{\mathrm{a}, \mathrm{b}}$, Taís S. Pereira ${ }^{\mathrm{a}}$, Marcos de Almeida ${ }^{\mathrm{a}}$, \\ Maria Clara L.F. Trindade ${ }^{a}$, Leonardo Menezes ${ }^{c}$, Alex. S. Caldas ${ }^{\text {a,c }}$ \\ a Núcleo de Estudos Ambientais, Instituto de Geociências, Universidade Federal da Bahia (UFBA), Campus de Ondina, 40170-290 Salvador, BA, Brazil \\ b Instituto de Geociências, Departamento de Geofisica Aplicada, Universidade Federal da Bahia (UFBA), Campus de Ondina, 40170-290 Salvador, BA, Brazil \\ ' Escola de Arquitetura, Engenharia e Tecnologia da Informação, Mestrado em Energia, Universidade Salvador (UNIFACS), Salvador, BA, Brazil
}

\section{A R T I C L E I N F O}

\section{Article history:}

Received 11 January 2016

Received in revised form 2 September 2016

Accepted 22 September 2016

Available online 30 September 2016

\section{Keywords:}

Oil-suspended particulate material aggregate

(OSA)

Oil spill

Ecological effects

\begin{abstract}
A B S T R A C T
For experiments concerning the formation of oil-suspended particulate matter (SPM) aggregates (OSA), oil and sediment samples were collected from Campos Basin and six stations of Paraguaçu estuary, Todos os Santos Bay, Brazil, respectively. The sediments samples were analyzed for organic matter determined by the EMBRAPA method, nitrogen determined by the Kjeldahl method, and phosphorus determined by the method described by Aspila. The oil trapped in OSA was extracted following the method described by Moreira. The experiment showed a relationship between the amount of organic matter and OSA formation and consequently the dispersion of the studied oil. On the basis of the buoyancy of OSA and the ecotoxicological effects on pelagic and benthic community, the priority areas for application of remediation techniques are Cachoeira, Maragogipe, and Salinas da Margarida because of the large amount of oil that accumulated at the bottom of the experiment flask (5.85\%, $27.95 \%$, and $38,98 \% ; 4.2 \%, 17.66 \%$, and $32.64 \%$; and $11.82 \%, 8.07 \%$, and $10.91 \%$ respectively).
\end{abstract}

(c) 2016 Elsevier Ltd. All rights reserved.

\section{Introduction}

Oil is the main source of global energy, whose related processes generally involve the marine environment. Because of this, there is a higher probability of accidents occurring at sea, such as oil spills from tankers, accidents on platforms, oil well explosion during operation, and local release of oil from a pipeline. Data show that about 5.66 million tons of oil, between 1970 and 2011, were released in the oceans because of these accidents (ITOPF, 2015). The risk of pollution by oil can also occur from illicit sources during routine operations of ships, such as deballasting. Some studies have shown that oil released in these cases is about eight times higher than the amount of oil released in accidental and negligent spills (Janeiro et al., 2014).

Negative effects are even greater when oil reaches the coast, because of its ability to reach sensitive ecosystems such as mangroves and coral reefs, leading to contamination and mortality of organisms, thereby endangering the human health and indirectly affecting social and economic processes. The severity of the effect depends on the processes involving the characteristics related to the spilled oil (volume and composition), the affected area, the time of occurrence of the accident, environmental and oceanographic conditions, and the method of remediation used, if any (Wang et al., 2007; Farias et al., 2008).

\footnotetext{
* Corresponding author.

E-mail address: icarotam@gmail.com (Í.T.A. Moreira).
}

Mangroves are typically found along tropical and subtropical coastal regions, and they are important because of their high rate of primary production that supports a wide range of aquatic organisms (Odum and Heald, 1972; Tam et al., 1998; Liu et al., 2014; Wang et al., 2014; Tansel et al., 2015). This ecosystem can be affected both when oil reaches the coast (as mentioned above) and by direct release of contaminants, because this ecosystem is usually situated near urban development and human activities (Wang et al., 2014).The deterioration of these areas is caused by the disordered occupation of coastal areas and the consumption of natural resources. The grievances to the environment, by the release of contaminants into the sea and coastal water bodies, are even higher because the majority of people still think that coastal water bodies are capable of diluting contaminants to safe levels for both humans and biota (Souza et al., 2016).

Because most contaminants that are released into mangrove swamps accumulate at the bottom, the sediment is considered both sink and source of contaminants. This source characteristic occurs due to the hydrodynamic patterns of mangroves that will always remobilize the sediment, turning contaminants available for water column and biota (Delvalls et al., 2004; Burton and Johnston, 2010; Bartoli et al., 2012; Souza et al., 2016). Environmental factors such as grain size distribution, salinity, $\mathrm{pH}$, redox potential, levels of organic matter (OM), winds, tides, freshwater input, and bioturbation will influence the retention of contaminants in the sediments, their bioavailability, and their potential toxicity (Pekey, 2006; Idris, 2008; Souza et al., 2016). 
The presence of oil in mangrove environments affects organisms through toxic actions. Reactive metabolites of some oil compounds can bind cellular proteins and DNA, leading to mutations, developmental malformations, tumors, and cancer. Several studies have shown a relationship between the occurrence of neoplasia and liver tumors in fish in the presence of some oil compounds (ICE, 2005; Soares-Gomes et al., 2010).

Because of the large environmental damage caused by accidents involving oil and the intentional release by population, and also because of the high cost of conventional removal techniques (which are often just as harmful as the spilled oil), researchers still look for cheap and effective ways to manage contaminated areas, which do not cause secondary damage to the environment (Sun et al., 2010).

The classical techniques of remediation and cleanup of a site contaminated by oil can be classified into mechanical/physical, chemical, and biological processes. These techniques intend to remove, disperse, or contain oil from spreading. Mechanical or physical techniques include manual removal of the contaminant, use of containment barriers, use of absorbent materials, blasting with water at different pressures, and others. The chemical methods involve the use of dispersants, which promote the breakage of oil into small droplets, causing the increase in pollutant degradation rate (CETESB, 2005). The biological methods involve bioremediation and phytoremediation; the former consists of adding nutrients, enzymes, and/or microorganisms to the environment to accelerate oil biodegradation rate (Vidali, 2001; Agarwal and Liu, 2015), and the latter uses plants and their associated microorganisms to clean contaminated areas (Pletsch et al., 2004; Moreira et al., 2013).

When oil is released into the marine environment, it is immediately subjected to weathering processes, which will promote changes to the original composition of the oil by a combination of physical, chemical, and biological processes (Szewczyk, 2006). These changes will determine the speed of degradation and the persistence of oil in the environment (Colombo et al., 2005).

The weathering processes include, among others, the dispersion of oil droplets in the water column. The interaction of these oil droplets with suspended particulate matter (SPM) in a turbulent aqueous environment results in the formation of oil-suspended particulate matter aggregate (OSA). OSA is a microscopic structure that remains stable for weeks (Stoffyn-Egli and Lee, 2002).

The interaction between oil and SPM occurs because of the characteristics related to oil, such as quantity, viscosity, and composition (Khelifa et al., 2002); sediment, such as particle size, quantity, mineralogical composition, and quantity of OM (Omotoso et al., 2002; Moreira et al., 2015); and the hydrodynamic characteristics of the environment, such as turbulence (Cloutier et al., 2002), temperature (Khelifa et al., 2002), and salinity (Le Floch et al., 2002). In fact, some studies have reported that the interactions between polar oil compounds and negatively charged particles form OSA (Guyomarch et al., 2002; Sørensen et al., 2013).

The formation of OSA has been considered as a natural cleaning process in oil-spilled coasts. The longer the time the oil remains in the water column, the higher is its rate of dispersion and biodegradation, thereby preventing the droplets to adhere to the stain again, because OSA decreases the adhesive properties of the oil (Muschenheim and Lee, 2002; Omotoso et al., 2002; Owens and Lee, 2003; Gong et al., 2014).

OSA can be classified according to their buoyancy. They can be negatively buoyant when the interaction between oil and SPM makes the aggregate denser than the water, causing OSA transportation to benthic compartment; neutral buoyant when OSA stay at the water column, which is beneficial to the environment because the longer OSA remains in the water column, the higher is the oil biodegradation rate; and positively buoyant when the arrangement between oil and SPM forms OSA with density less than water, and so they remain in the top layers of water (Gong et al., 2014; Moreira et al., 2015; Zhao et al., 2016).
Because of the buoyancy, OSA can be an important tool in cases of oil spills, because they will guide the management of contaminated areas indicating the likely path of the spilled oil in the water column (Moreira, 2014; Moreira et al., 2015). Therefore, it is important to know the mechanism of formation of aggregates in any area with potential risk of oil accidents.

This study was conducted in the Paraguaçu estuary, which is located in the western boundary of Todos os Santos Bay (BTS, acronym in Portuguese for Baía de Todos os Santos).

This estuary has both biological and social importance, because it has an extensive area of mangroves, which is one of the most productive and diverse environments in the world, besides being a source of income for people who live close to these environments (Barros et al., 2008).

The BTS has a history of contamination related to the activities of the oil industry. The Paraguaçu estuary used to be the most preserved region of BTS, but studies have shown a gradual contamination of the area for petroleum compounds (Veiga, 2003; Celino and Queiroz, 2006; Rios, 2014).

Contamination of Paraguaçu estuary occurs mainly because of the release of domestic and industrial effluents and the effects caused by the São Roque's shipyard. There are also indirect effects caused by the large number of oil industries in BTS (Bahia, 2009; Almeida, 2014; Rios, 2014; Pereira et al., 2015).

The contamination situation can become worse because of the inauguration of the new Paraguaçu shipyard in 2014. Thus, it is important to know how the estuary naturally behaves in a hypothetical oil spill in the area. Therefore, this study aims to (1) evaluate at laboratory scale the capability of sediment of the Paraguaçu estuary to form OSA and (2) study the buoyancy of OSA formed in the experiment and define areas of significant ecological risks in case of oil spills.

\section{Materials and methods}

\subsection{Study area}

Paraguaçu River is considered the most important river in the state of Bahia. It has a drainage basin of about $55,317 \mathrm{~km}^{2}$ and is the main sub-basin of the BTS drainage system, which has $60,500 \mathrm{~km}^{2}$ (Genz, 2006). This estuarine system has high value to the population inhabiting it, as it provides a source of food and income (i.e., consumption and commercialization of fish). Besides, it also harbors a large amount of fauna and flora that need to be preserved (Barros et al., 2008).

The climate of the study area is hot and humid, with the rainy season from April to September and the dry season from October to March. The estuary's area has a precipitation ranging from 1200 to $1600 \mathrm{~mm}$, and the average annual temperature is $24^{\circ} \mathrm{C}$, where the months from November to March have the highest temperatures, while the months from July to August have the lowest (Genz, 2006).

\subsection{Sampling and pretreatment}

Fieldwork was performed on 18 July 2013, during the rainy season in the Paraguaçu estuary. Six sampling stations located near the cities of Cachoeira (P 01), Coqueiros (P 02), Maragogipe (P 03), São Roque (P 04), and Salinas da Margarida (P 05 and P 06) were selected. Two sites were selected in Salinas da Margarida, with one facing the estuary (P 05) and the other facing the BTS (P 06). These six sites were chosen on the basis of literature searches, satellite images, and maps (Fig. 1).

At each sampling station, three water samples were collected in $500 \mathrm{ml}$ amber bottles, except P 06 because of the risk to researchers.

Composite samples of surface sediment of each station were collected. This sediment was collected manually with stainless steel spoons, homogenized in glass dishes, and stored in glass recipients. All sediment samples were collected in triplicate. The samples were transported to 


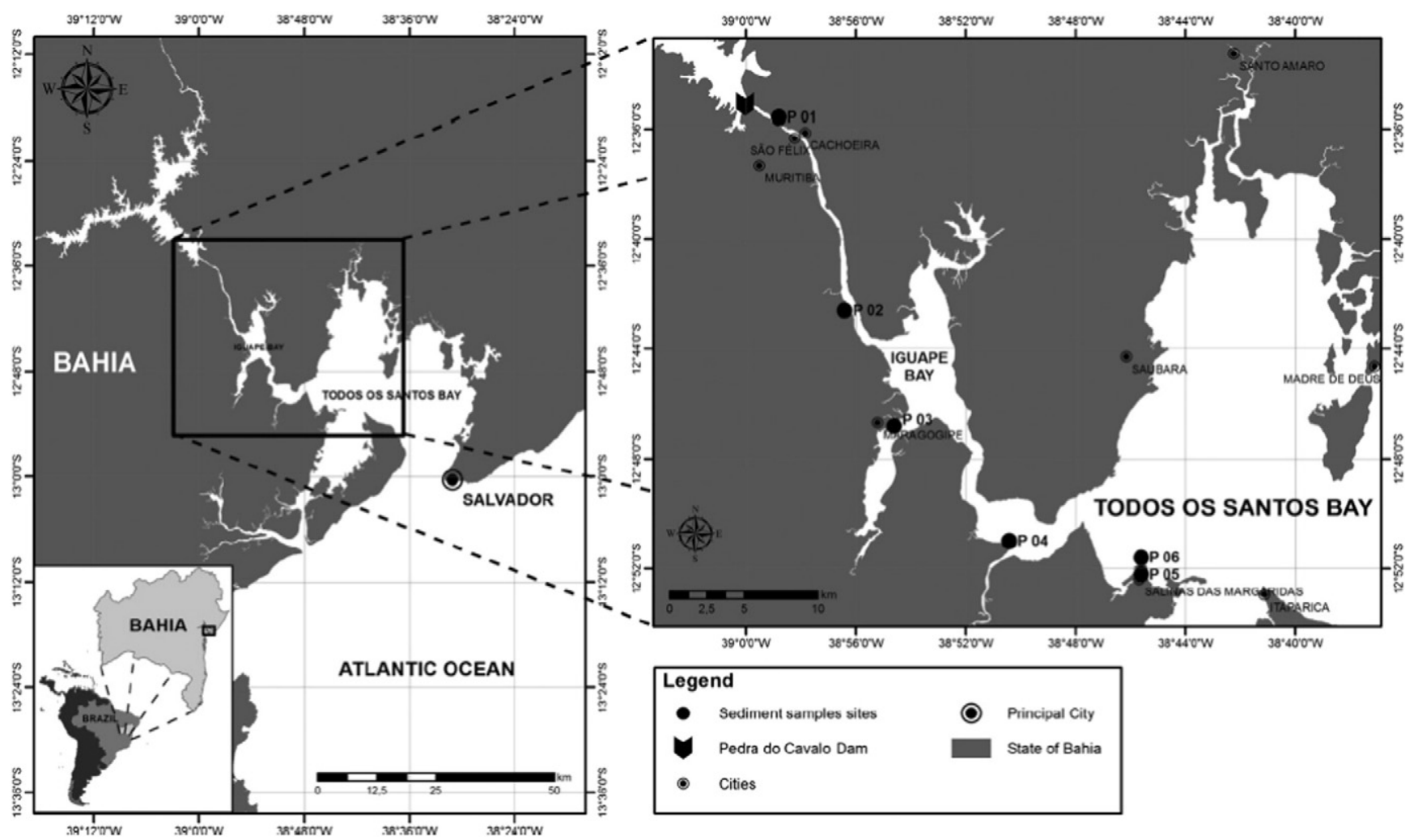

Fig. 1. Map of the Paraguaçu estuary and the sampling stations (Pereira et al., 2015).

the laboratory in coolers and then stored in a freezer with average temperature of $-20^{\circ} \mathrm{C}$.

In the laboratory, sediment samples were lyophilized and disaggregated to conduct the analyses. These samples were then passed through 0.06- and 0.5-mm sieves. Samples that passed through the mesh of $0.5 \mathrm{~mm}$ were used for the analyses of total nitrogen determined by the Kjeldahl method (EMBRAPA, 2009); available phosphorus was determined by the method described by Aspila et al. (1976); and OM was determined by the EMBRAPA method (EMBRAPA, 2009). Samples that passed through the mesh of $0.06 \mathrm{~mm}$ (silt and clay) were used in the experiment of OSA formation.

Water samples were filtered through glass fiber filters, which were used for the analysis of particulate organic carbon determined by the EMBRAPA method (EMBRAPA, 2009).

\subsection{OSA formation experiment}

The experiment of OSA formation followed the protocol proposed by Moreira et al. (2015). It was performed in $500 \mathrm{ml}$ Erlenmeyer flasks, and in each flask, $250 \mathrm{ml}$ of artificial saline water was added, according to the salinity found in situ in each sampling station (Table 1).

For each sampling station, three different concentrations of sediment, a replica of one of these concentrations, and a blank (containing only saline water and oil) were tested, that is, five samples for each station, totaling 30 samples (Table 2).

Table 1

Salinity found in situ at each sampling station.

\begin{tabular}{ll}
\hline Sampling station & Salinity \\
\hline P 01 & 0 \\
P 02 & 20 \\
P 03 & 27 \\
P 04 & 30 \\
P 05 & 35 \\
P 05 & 35 \\
\hline
\end{tabular}

Sediment samples, as mentioned above, were treated so that its particle size would be composed of only silt and clay. After addition of the sediments, the Erlenmeyer flasks were placed in a reciprocating shaker table and were shaken at the maximum speed for $1 \mathrm{~min}$, so that the sediments were hydrated facilitating cationic exchange (Khelifa et al., 2007).

The oil used in the experiment was obtained from Campos Basin. The mass of oil added to each Erlenmeyer flask was $90 \mathrm{mg}$. Before addition to the Erlenmeyer flask, the oil was subjected to rapid stirring for 30 min to increase its fluidity.

Once saline water, oil, and sediment were added, the Erlenmeyer flasks were connected to a reciprocating shaker table and kept there for $3 \mathrm{~h}$ with a stirring of 126 cycles min $^{-1}$. After stirring, the flasks were removed from the shaker table and were allowed to settle overnight, so that OSA with different buoyancies were separated by gravity.

Aliquots of $50 \mathrm{ml}$ were taken from the middle part and bottom of each Erlenmeyer flask to quantify OSA with neutral buoyancy and negative buoyancy. The extraction process followed the method described by Moreira et al. (2015).

Table 2

Sediment concentration added to each Erlenmeyer flask.

\begin{tabular}{ll}
\hline Sampling station & Sediment concentration $\left(\mathrm{mg} \mathrm{L}^{-1}\right)$ \\
\hline P 01 & $50,50 \mathrm{R}, 200,300, \mathrm{BL}$ \\
P 02 & $50,200,200 \mathrm{R}, 300, \mathrm{BL}$ \\
P 03 & $50,200,300,300 \mathrm{R}, \mathrm{BL}$ \\
P 04 & $50,50 \mathrm{R}, 200,300, \mathrm{BL}$ \\
P 05 & $50,200,200 \mathrm{R}, 300, \mathrm{BL}$ \\
P 06 & $50,200,300,300 \mathrm{R}, \mathrm{BL}$ \\
\hline
\end{tabular}

$\mathrm{BL}=$ Blank; 50R $=$ Replica of concentration $50 \mathrm{mg} \mathrm{L}^{-1} ; 200 \mathrm{R}=$ Replica of concentration $200 \mathrm{mg} \mathrm{L}^{-1}$; 300R = Replica of concentration $300 \mathrm{mg} \mathrm{L}^{-1}$. 


\subsection{Statistical analyses}

Principal component analysis (PCA) and Pearson correlation analysis were the statistical tests performed to better understand how each factor influenced OSA formation. All statistical evaluations were performed using the STATISTICA 9.0 and GraphPad Software packages.

\section{Results and discussion}

\subsection{Characteristics of sediments}

The results of the concentration of OM in the sediment, SPM of water, organic carbon in suspended particulate matter (COP), total nitrogen (Nt) in sediment, and available phosphorus $(\mathrm{P})$ in sediment are shown in Table 3.

In the sampling stations, SPM concentrations range from 0 to $124 \mathrm{mg}$ $\mathrm{L}^{-1}$. According to Boehm (1987), the rate of aggregation between oil and SPM is very low for SPM concentrations ranging from 1 to $10 \mathrm{mg}$ $\mathrm{L}^{-1}$; there is a considerable aggregation in the concentration range of $10-100 \mathrm{mg} \mathrm{L}^{-1}$, and at concentrations $>100 \mathrm{mg} \mathrm{L}^{-1}$, aggregation rates are high. The large amount of SPM at P 03 indicates that this is a promising region in relation to OSA formation. There may be more efficient dispersion if a spill occurs in this area. However, this measurement was performed in the rainy season, which means that a larger load of sediment will be in suspension. Because of this, it is important to evaluate with a longer time scale, so that it is possible to affirm the exact event in the region.

Another factor that influences OSA formation is the amount of OM in the sediment, especially the amount that is present in the particulate material (Gong et al., 2014; Moreira et al., 2015). The concentrations of OM for this study ranged from $0.38 \%$ to $3.00 \%$ in the sediment and 1.23 to $3.90 \mathrm{mg} \mathrm{L}^{-1}$ for organic COP. These values are considered low for this type of environment, and this may be associated with a relatively high hydrodynamics in the area (Bahia, 2009; Lessa and Dias, 2009; Salles, 2010).

The highest values of OM were found at P 05, which is located in the innermost part of the beach, facing the river. This sampling station was near a harbor for boats, which can be a source of contamination by OM (Nemr et al., 2005; Paladino et al., 2015; Lemos et al., 2015). The lowest values were found at P 04, and can be explained by the particle size of the sediment that is more sandy than in other areas, making it difficult for OM accumulation (Gireeshkumar et al., 2013; Yang et al., 2015).

The presence of the nutrients nitrogen and phosphorus in the sediment positively helps oil biodegradation processes, especially combined with the formation of OSA, which accelerates these processes (Bao et al., 2012; Silva et al., 2015). The total nitrogen varied between less than the quantification limit (QL) and $0.22 \%$, which are relatively low values. The presence of this element is mainly related to the state of decomposition of OM from the roots and leaves of mangrove, seawater, and anthropogenic contributions, as effluents from sewage (Vannucci, 2002; Pereira et al., 2015). The available phosphorus varied between 40.93 and $230.57 \mathrm{mg} \mathrm{kg}^{-1}$. The station with the highest phosphorus content was

Table 3

Concentrations of geochemical parameters determined in the surface sediment samples and water of Paraguaçu estuary.

\begin{tabular}{llllll}
\hline Sampling station & POC $\left(\mathrm{mg} \mathrm{L}^{-1}\right)$ & OM (\%) & $\mathrm{Nt}(\%)$ & $\mathrm{P}\left(\mathrm{mg} \mathrm{kg}^{-1}\right)$ & $\mathrm{SPM}\left(\mathrm{mg} \mathrm{L}^{-1}\right)$ \\
\hline P 01 & 1.23 & 2.82 & 0.18 & 207.77 & 0 \\
P 02 & 1.72 & 0.62 & $<\mathrm{QL}$ & 217.87 & 40.67 \\
P 03 & 3.90 & 2.68 & 0.10 & 230.57 & 124.00 \\
P 04 & 3.41 & 0.38 & $<\mathrm{QL}$ & 40.93 & 118.00 \\
P 05 & 2.11 & 3.00 & 0.22 & 169.60 & 88.67 \\
P 06 & 1.68 & 1.04 & $<\mathrm{QL}$ & 119.10 & 79.56 \\
\hline
\end{tabular}

$\mathrm{POC}=$ particulate organic carbon; $\mathrm{OM}=$ organic matter; $\mathrm{Nt}=$ total nitrogen; $\mathrm{P}=$ available phosphorus; $\mathrm{SPM}=$ suspended particulate matter; $<\mathrm{QL}=$ less than quantification limit.
P 03, and the lowest was P 04. These values are in agreement with previous results, which indicate that Paraguaçu estuary is oligotrophic (Bahia, 2009; Pereira et al., 2015).

\subsection{OSA formation experiment}

\subsubsection{Sediment capability to form OSA}

The results of the experiment of OSA formation are presented in Fig. 2. It shows the percentage of oil dispersed by SPM (oil that formed OSA) according to the amount of oil added initially to each Erlenmeyer flask of the experiment.

At P 01, the percentage of oil forming OSA was $6.65 \%$ at sediment concentration of $50 \mathrm{mg} \mathrm{L}^{-1}, 28.86 \%$ at $200 \mathrm{mg} \mathrm{L}^{-1}$, and $40.11 \%$ at concentration of $300 \mathrm{mg} \mathrm{L}^{-1}$. At P 02 , the corresponding percentages were $6.48 \%, 10.18 \%$, and $16.37 \%$. At P 03 , the amounts of oil dispersion were $6.48 \%, 20.91 \%$, and $36.03 \%$ at the same sediment concentrations. These values are in agreement with previous studies showing that the larger the amount of SPM available on the medium, the higher is the formation of OSA (Ajijolaiya et al., 2006; Sun and Zheng, 2009; Sun et al., 2010; Moreira, 2014).

However, the values found at P 04, P 05, and P 06 did not obey the rule that more OSA are formed with larger amount of SPM. These results can be explained by the density of the sediment used. According to Schön (1996), three factors influence the sediment density: mineral composition, porosity, and saturation conditions. Therefore, the mineralogy of these three sediment samples may have caused them to be denser than the previous three sediments. Thus, the mixing energy used in the experiment may not have been sufficient to put these sediment samples in suspension. Consequently, the mixing energy was more important than the amount of SPM (Ma et al., 2008; Wincele et al., 2004; Trindade, 2011).

As the Paraguaçu estuary has a relatively high hydrodynamic resistance (Bahia, 2009; Lessa and Dias, 2009; Salles, 2010), the density of the sediment would not influence much, like in the last three experiments (P 04, P 05, and P 06), because it will always have a good amount of fine sediment in suspension, so that OSA formation can occur.

At the three sediment concentrations, increase in the amount of OSA formed with salinity was not observed as discussed in several works (Le Floch et al., 2002; Sun and Zheng, 2009; Santos, 2010; Bandara et al., 2011; Gong et al., 2014). This result showed that the sedimentary features of each station, as the amount of OM associated with the sediment, made salinity a secondary factor in the aggregation. This is in agreement with Moreira et al. (2015).

\subsubsection{Buoyancy of OSA}

Many studies have been conducted on the factors affecting OSA formation, the conditions under which they are formed, and the potential of the sediment to form the aggregate. However, Moreira et al. (2015) attempted to evaluate the ecological risks of oil dispersed by OSA formation to the benthic environment. When OSA have negative buoyancy, because of changes in aggregate density (Stoffyn-Egli and Lee, 2002; Sterling et al., 2004), they can be an important and dangerous vector of contamination in the benthic environment and can lead to mortality of marine animals present in this environment, because of oil toxicity and hence an ecological imbalance.

The buoyancies of OSA formed in each of the sampling stations are shown in Table 4.

It was observed that with the sediments collected at P $04, \mathrm{P} 03$, and P 06 , there was a higher amount of OSA with neutral buoyancy than the sediments of the other three stations. OSA with neutral buoyancy are the most beneficial to the environment, because the longer the OSA remain in the water column, the higher is the oil biodegradation rate (Lee et al., 1996; Weise et al., 1999; Muschenheim and Lee, 2002; Owens and Lee, 2003; Gong et al., 2014).

The largest amount of OSA with neutral buoyancy in these stations should be related to the way in which oil droplets and the SPM are 


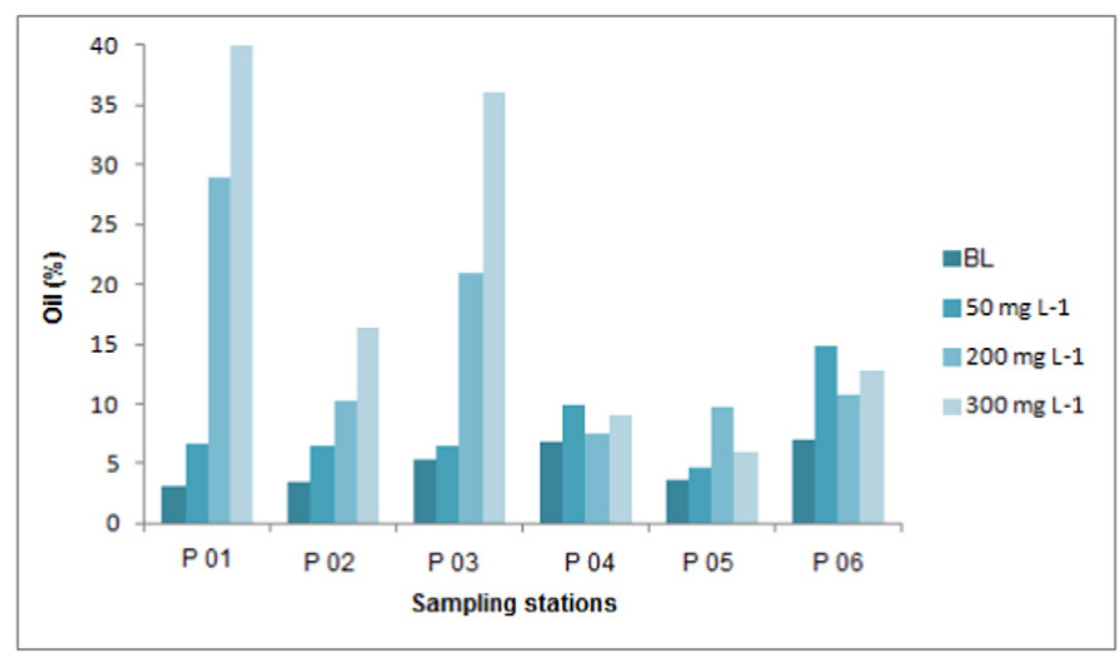

Fig. 2. Amount of oil dispersed by SPM in the blank and sediment concentrations of 50, 200, and $300 \mathrm{mg} \mathrm{L}^{-1}$.

arranged within the OSA, making much of the OSA to have a density close to that of water (Stoffyn-Egli and Lee, 2002).

In a hypothetical case of oil spill in the area, on the basis of the results of this study, the priority actions for remediation should be employed first at P 01 , since this station has the highest chance of contamination risk to the benthic environment.

To make a more accurate diagnosis of the area, it would be important to conduct an experiment on a larger scale to confirm that the behavior of these OSA would be the same in a larger water column.

\subsection{Statistical treatment}

PCA and Pearson correlation analysis were the statistical analysis techniques used in this study to better understand how each factor influenced the formation of the OSA. The analyses were performed using STATISTICA 9.0 ® software (STATSOFT, 2009).

The PCA used in this experiment showed that the two main components could explain $71.32 \%$ of the variation in the data considered, with the first factor explaining 53.09\% and the second explaining $18.23 \%$.

The values of OM, phosphorus, nitrogen, clay, silt, salinity, OSA formed in the column (at concentrations of 50, 200, and $300 \mathrm{mg} \mathrm{L}^{-1}$ ), OSA formed at the bottom (at the same concentrations), and the total OSA (at the same concentrations) are represented in Fig. 3a.

There was a strong positive influence on the amount of silt and clay in the OSA formation and a strong negative influence on salinity, mainly at the bottom, which were the ones that formed more OSA. Salinity promotes the formation of OSA, because with a higher concentration of ions available in the environment, there is more interaction between the sediment particles and oil droplets (Sun and Zheng, 2009; Bandara et al., 2011; Gong et al., 2014). However, it was seen that for this

Table 4

Dispersed oil (\%) by OSA formation at sediment concentrations of 50, 200, and $300 \mathrm{mg} \mathrm{L}^{-1}$, in the column (C) and at the bottom (B) of the Erlenmeyer flasks.

\begin{tabular}{lllllll}
\hline $\begin{array}{l}\text { Sampling } \\
\text { station }\end{array}$ & $\begin{array}{l}\text { OSA50 } \\
(\mathrm{B})(\%)\end{array}$ & $\begin{array}{l}\text { OSA200 } \\
(\mathrm{B})(\%)\end{array}$ & $\begin{array}{l}\text { OSA300 } \\
(\mathrm{B})(\%)\end{array}$ & $\begin{array}{l}\text { OSA50 } \\
(\mathrm{C})(\%)\end{array}$ & $\begin{array}{l}\text { OSA200 } \\
(\mathrm{C})(\%)\end{array}$ & $\begin{array}{l}\text { OSA300 } \\
(\mathrm{C})(\%)\end{array}$ \\
\hline P 01 & 5.85 & 27.95 & 38.98 & 0.8 & 0.91 & 1.14 \\
P 02 & 3.41 & 8.81 & 14.89 & 3.07 & 1.37 & 1.48 \\
P 03 & 4.2 & 17.66 & 32.64 & 2.27 & 3.25 & 3.39 \\
P 04 & 5.28 & 4.55 & 6.7 & 4.61 & 2.95 & 2.27 \\
P 05 & 3.52 & 7.56 & 4.89 & 1.14 & 2.22 & 1.14 \\
P 06 & 11.82 & 8.07 & 10.91 & 2.95 & 2.61 & 1.82 \\
\hline
\end{tabular}

experiment, salinity was not the main factor of OSA formation; hence, this factor had a negative correlation. The amounts of silt and clay are important as they are the smallest fractions of the sediment, and OSA are better formed with these fractions because of the higher specific surface area (Sun and Zheng, 2009).

OSA formed at the bottom and total OSA, at concentrations of 200 and $300 \mathrm{mg} \mathrm{L}^{-1}$, are associated with the presence of OM and phosphorus in the sediment. The presence of OM increases the amount of aggregates, because it increases the strength of the interaction between hydrocarbons and sedimentary particles due to the chemical affinity (Muschenheim and Lee, 2002). OM can also increase the sediment density, so that it has negative buoyancy.

OSA formed at the bottom and total OSA, at a concentration of $50 \mathrm{mg}$ $\mathrm{L}^{-1}$, were not well represented in the PCA plot.

The formation of the column OSA at all three sediment concentrations had no correlation among geochemical variables tested, and it can be attributed to the mineral composition of the sediment, which will influence the internal structure (arrangement) of the OSA, causing it to have a density close to that of saline water (Stoffyn-Egli and Lee, 2002).

From a combined interpretation of Fig. 3a and b, it is possible to establish a relationship between geochemical parameters and sediment of each sampling station. The formation of OSA in P 02 and P 05 was mainly controlled by the amount of clay and silt present in the sediments. The sediment samples of P 03 and P 01 had higher influence of OM in OSA formation and strong correlation with bottom OSA and total OSA, as more aggregates were formed in these two stations. However, P 04 did not have any influence on the geochemical parameters that were analyzed, but had a strong correlation with column OSA. Finally, P 06 was influenced by salinity in the formation of OSA.

The analysis of Pearson correlation (Table 5) showed that bottom OSA and total OSA at sediment concentration of $200 \mathrm{mg} \mathrm{L}^{-1}$ correlated positively and highly with OM, which makes sense because the amount of OM influences the formation of aggregates, in accordance with the above discussion. Total and bottom OSA at concentration of $300 \mathrm{mg}$ $\mathrm{L}^{-1}$ were also correlated with $\mathrm{OM}$, but not as strong as that at the concentration of $200 \mathrm{mg} \mathrm{L}^{-1}$ (Muschenheim and Lee, 2002).

Silt fraction had a positive correlation with total and bottom OSA at the concentration of $200 \mathrm{mg} \mathrm{L}^{-1}$, and a weaker but significant correlation with the total and bottom OSA at the concentration of $300 \mathrm{mg}$ $\mathrm{L}^{-1}$. Since the sediment that was used in the experiment had higher silt concentrations than clay concentrations, OSA were preferably formed with silt, which is also capable of forming aggregates (Sun and Zheng, 2009; Silva, 2014; Moreira, 2014). 

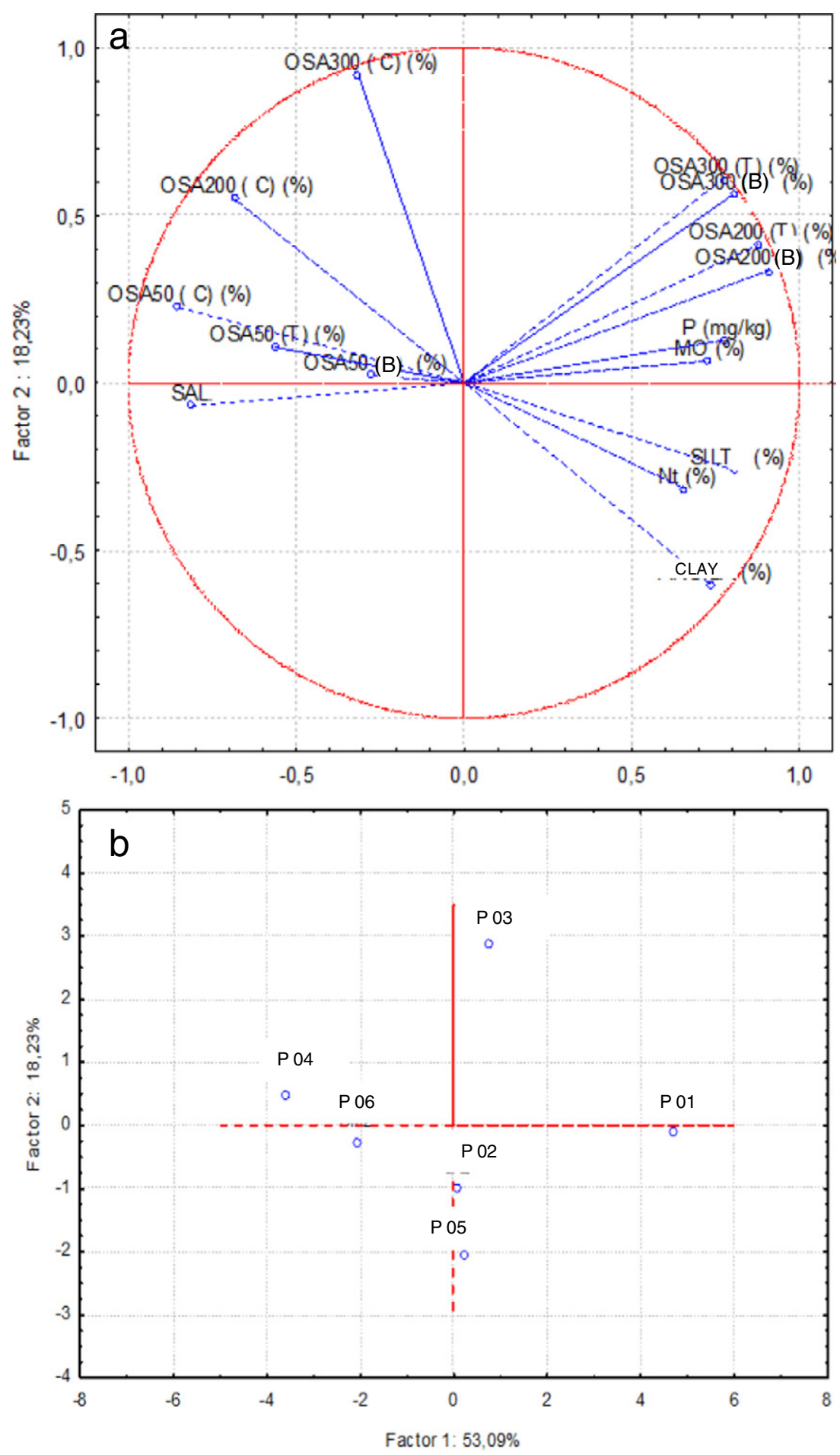

Fig. 3. Principal component analysis between oil associated with OSA and geochemical parameters measured in sediment used in the experiment.

Total OSA at all sediment concentrations had a strong positive correlation with bottom OSA in all concentrations, reaffirming the tendency of the experiment to form OSA with negative buoyancy (Moreira, 2014).

\section{Conclusions}

The sedimentary samples collected in Paraguaçu estuary have little capability to form OSA because of their geochemical and textural characteristics. Still, the station with the highest capability to form OSA was P 01, followed by P 03, P 06, P 02, P 04, and P 05.
The experiment tends to form OSA with negative buoyancy; however, as the water column in the Erlenmeyer is very small compared to that in the estuary, it is possible that much of OSA that settled at the bottom in the experiment remain in the water column of an estuarine environment long enough for biodegradation, before the oil reaches the benthic environment.

Sites that formed a considerable amount of OSA with neutral buoyancy have a good chance to recover naturally, because of the increase in biodegradation rates related to the formation of OSA, so they would not be priority areas when remediation actions were taken in the affected areas. 
Table 5

Pearson correlation matrix applied in the formation and dispersion of OSA.

\begin{tabular}{|c|c|c|c|c|c|c|c|c|c|c|c|c|c|c|c|}
\hline & SAL & $\mathrm{Nt}$ & $\mathrm{P}$ & $\mathrm{OM}$ & SILT & CLAY & OSA50T & OSA200T & OSA300T & OSA50B & OSA200B & OSA300B & OSA50C & OSA200C & OSA300C \\
\hline SAL. & 1.00 & & & & & & & & & & & & & & \\
\hline Nt (\%) & -0.26 & 1.00 & & & & & & & & & & & & & \\
\hline $\mathrm{P} \mathrm{mg} \mathrm{kg}^{-1}$ & -0.46 & 0.38 & 1.00 & & & & & & & & & & & & \\
\hline OM (\%) & -0.26 & 0.90 & 0.58 & 1.00 & & & & & & & & & & & \\
\hline SILT (\%) & -0.78 & 0.26 & 0.70 & 0.27 & 1.00 & & & & & & & & & & \\
\hline CLAY (\%) & -0.56 & 0.61 & 0.47 & 0.47 & 0.83 & 1.00 & & & & & & & & & \\
\hline OSA50 (T) (\%) & 0.34 & -0.65 & -0.60 & -0.58 & -0.25 & -0.25 & 1.00 & & & & & & & & \\
\hline OSA200 (T) (\%) & -0.80 & 0.45 & 0.60 & 0.65 & 0.60 & 0.44 & -0.30 & 1.00 & & & & & & & \\
\hline OSA300 (T) (\%) & -0.75 & 0.22 & 0.64 & 0.50 & 0.54 & 0.23 & -0.26 & 0.95 & 1.00 & & & & & & \\
\hline OSA50 (B) (\%) & 0.20 & -0.36 & -0.39 & -0.27 & -0.03 & 0.06 & 0.93 & -0.06 & -0.10 & 1.00 & & & & & \\
\hline OSA200 (B) (\%) & -0.84 & 0.46 & 0.62 & 0.63 & 0.66 & 0.51 & -0.32 & 1.00 & 0.94 & -0.07 & 1.00 & & & & \\
\hline OSA300 (B) (\%) & -0.78 & 0.25 & 0.65 & 0.51 & 0.58 & 0.29 & -0.27 & 0.97 & 1.00 & -0.10 & 0.95 & 1.00 & & & \\
\hline OSA50 (C) (\%) & 0.44 & -0.88 & -0.68 & -0.90 & -0.61 & -0.80 & 0.52 & -0.65 & -0.47 & 0.16 & -0.68 & -0.50 & 1.00 & & \\
\hline OSA200 (C) (\%) & 0.77 & -0.33 & -0.43 & -0.14 & -0.89 & -0.85 & 0.33 & -0.39 & -0.27 & 0.16 & -0.48 & -0.32 & 0.50 & 1.00 & \\
\hline OSA300 (C) (\%) & 0.31 & -0.42 & -0.01 & -0.07 & -0.54 & -0.82 & 0.13 & 0.05 & 0.28 & -0.03 & -0.04 & 0.22 & 0.41 & 0.80 & 1.00 \\
\hline
\end{tabular}

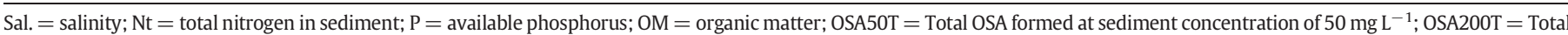

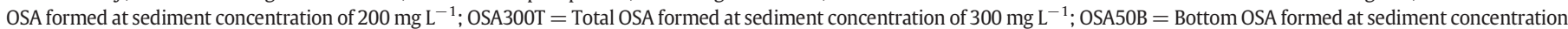

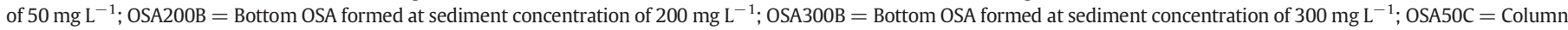

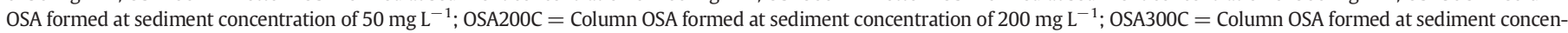
tration of $300 \mathrm{mg} \mathrm{L}^{-1}$.

Bold values are the most significant correlations for this study.

The places where OSA are formed with large negative buoyancy should be the first areas for application of containment and remediation measures in order to avoid heavy losses in local diversity, generating major ecological imbalances.

Thus, because of the ecological risks, the priority areas for the application of remediation techniques would be $\mathrm{P} 01, \mathrm{P} 03$, and $\mathrm{P} 06$, followed by P 02, P 04, and P 05.

\section{References}

Agarwal, A., Liu, Y., 2015. Remediation technologies for oil-contaminated sediments. Mar. Pollut. Bull. 101, 483-490.

Ajijolaiya, L.O., Hill, P.S., Khelifa, A., Islam, R.M., Lee, K., 2006. Laboratory investigation of the effects of mineral size and concentration on the formation of oil-mineral aggregates. Mar. Pollut. Bull. 52, 920-927.

Almeida, M., 2014. Distribuição e Origem de Hidrocarbonetos Policíclicos Aromáticos em Sedimentos Superficiais da Zona Intermareal do Estuário do rio Paraguaçu, Bahia (Monografia (Graduação em Oceanografia)) Instituto de Geociência, Universidade Federal da Bahia.

Aspila, K.I., Agemian, H., Chau, A.S.Y., 1976. A semi-automated method for the determination of inorganic, organic and total phosphate in sediments. Analyst 101, 187-197.

Bahia, 2009. Estudo de Impacto Ambiental e Relatório de Impacto Ambiental (EIA/RIMA) do Estaleiro do Paraguaçu. Meio físico 303 Bahia.

Bandara, U.C., Yapa, P.D., Xie, H., 2011. Fate and transport of oil in sediment laden marine waters. J. Hydro Environ. Res. 5, 145-156.

Bao, M., Wang, L., Sun, P., Cao, L., Zou, J., Li, Y., 2012. Biodegradation of crude oil using an efficient microbial consortium in a simulated marine environment. Mar. Pollut. Bull. $64,1177-1185$.

Barros, F., Hatje, V., Figueredo, M.B., Magalhães, W.F., Dórea, H.S., Emídio, E.S., 2008. The structure of the benthic macrofaunal assemblages and sediments characteristics of the Paraguaçu estuarine system, NE, Brazil. Estuar. Coast. Shelf Sci. 78, 753-762.

Bartoli, G., Papa, S., Sagnella, E., Fioretto, A., 2012. Heavy metal content in sediments along the Calore river: relationships with physical e chemical characteristics. J. Environ. Manag. 95, 9-14.

Boehm, P.D., 1987. Transport and transformation processes regarding hydrocarbon and metal pollutants in offshore sedimentary environments. In: Boesch, D.F., Rabalais, N.N. (Eds.), Long-Term Environmental Effects of Offshore Oil and Gas Development. Elsevier Applied Science, London, pp. 233-287.

Burton, G.A., Johnston, E.L., 2010. Assessing contaminated sediments in the context of multiple stressors. Environ. Toxicol. Chem. 29, 2625-2643.

Celino, J.J., Queiroz, A.F.S., 2006. Fonte e grau da contaminação por hidrocarbonetos policíclicos aromáticos (HPAs) de baixa massa molecular em sedimentos da baía de Todos os Santos, Bahia. Revista Escola de Minas 3, 265-270.

CETESB, 2005. Aspectos físicos e químicos do óleoAvailable in http://www.cetesb.sp.gov. $\mathrm{br} /$ gerenciamento-de-riscos/vazamento-de-oleo/222-aspectos-fisico-quimicos (Access in 03/03/16).

Cloutier, D., Amos, C.L., Hill, P.R., Lee, K., 2002. Oil erosion in an annular flume by seawater of varying turbidities: a critical bed shear stress approach. Spill Sci. Technol. Bull. 8, 3-8.

Colombo, J.C., Barreda, A., Bilos, C., Cappelletti, N., Migoya, M.C., Skorupka, C., 2005. Oil spill in the Rio de la Plata Estuary, Argentina: 2-hydrocarbon disappearance rates in sediments and soils. Environ. Pollut. 134, 267-276.
DelValls, T.A., Andres, A., Belzunce, M.J., Buceta, J.L., Casado-Martinez, M.C., Castro, R., Riba, I., Viguri, J.R., Blasco, J., 2004. Chemical and ecotoxicological guidelines for managing disposal of dredged material. TrAC Trends Anal. Chem. 23, 819-828.

EMBRAPA. Centro Nacional de Pesquisa de Solos, 2009. Manual de métodos análises químicas para avaliação de fertilidade do solo. second ed. Embrapa Informações Tecnológicas, Brasília, Brazil (627 p).

Farias, C.O., Hamacher, C., Wagener, A.L.R., Scofield, A.L., 2008. Origin and degradation of hydrocarbons in mangrove sediments (Rio de Janeiro, Brazil) contaminated by an oil spill. Org. Geochem. 39, 289-307.

Genz, F., 2006. Avaliação dos Efeitos da Barragem de Pedra do Cavalo Sobre a Circulação Estuarina do Rio Paraguaçu e Baía de Iguape (Tese (Doutorado em Geologia)) Instituto de Geociências, Universidade Federal da Bahia.

Gireeshkumar, T.R., Deepulal, P.M., Chandramohanakumar, N., 2013. Distribution and sources of sedimentary organic matter in a tropical estuary, south west coast of India (Cochin estuary): a baseline study. Mar. Pollut. Bull. 66, 239-245.

Gong, Y., Zhao, X., Cai, Z., O'Reilly, S.E., Hao, X., Zhao, D., 2014. A review of oil, dispersed oil and sediment interactions in the aquatic environment: influence on the fate, transport and remediation of oil spills. Mar. Pollut. Bull. 79, 16-33.

Guyomarch, J. Le Floch, S., Merlin, F.-X., 2002. Effect of suspended mineral load, water salinity and oil type on the size of oil-mineral aggregates in the presence of chemical dispersant. Spill Sci. Technol. Bull. 8, 95-100.

ICES, 2005. Review of analytical methods for determining metabolites of polycyclic aromatic compounds (PACs) in fish bile. By F. Ariese, J. Beyer, G. Jonsson, C. Porte, and M. M. Krahn. ICES Techniques in Marine Environmental Sciences No. 39, 41.

Idris, A.M., 2008. Combining multivariate analysis and geochemical approaches for assessing heavy metal level in sediments from Sudanese harbors along the Red Sea coast. Microchem. J. 90, 159-163.

ITOPF. 2015. International Tanker Owners Pollution Federation Limited. London, United Kingdom. Available in: http://www.itopf.com/. Access in: September 30th, 2015.

Janeiro, J., Zacharioudaki, A., Sarhadi, E., Neves, A., Martins, F., 2014. Enhancing the management response to oil spills in the Tuscany archipelago through operational modelling. Mar. Pollut. Bull. 85, 574-589.

Khelifa, A., Stoffyn-Egli, P., Hill, P.S., Lee, K., 2002. Characteristics of oil droplets stabilized by mineral particles: effect of oil types and temperature. Spill Sci. Technol. Bull. 8, 3-8.

Khelifa, A., Fieldhouse, B., Wang, Z., Yang, C., Landriault, M., Fingas, M.F., Brown, C.E., Gamble, L., 2007. A laboratory study on formation of oil-SPM aggregates using the NIST standard reference material 1941b. Proceedings of the Thirtieth Arctic and Marine Oil Spill Program Technical Seminar. Environment Canada, Ottawa, Ontario, pp. 35-48.

Le Floch, S., Guyomarch, J., Merlin, F.X., Stoffyn-Egli, P., Dixon, J., Lee, K., 2002. The influence of salinity on oil-mineral aggregate formation. Spill Sci. Technol. Bull. 8, 65-71.

Lee, K., Weise, A.M., St.-Pierre, S., 1996. Enhanced oil biodegradation with mineral fine interaction. Spill Sci. Technol. Bull. 3, 263-267.

Lemos, R.T.O., Carvalho, P.S.M., Zanardi-Lamardo, E., 2015. Petroleum hydrocarbons in water from a Brazilian tropical estuary facing industrial and port development. Mar. Pollut. Bull. 82, 183-188.

Lessa, G., Dias, K., 2009. Distribuição espacial das litofácies de fundo da Baía de Todos os Santos. Quaternary Environ. Geosci. 1, 84-97.

Liu, L., Li, F., Yang, Q., Tam, N.F.Y., Liao, W., Zan, Q., 2014. Long-term differences in annual litter production between alien (Sonneratia apetala) and native (Kandelia obovata) mangrove species in Futian, Shenzhen, China. Mar. Pollut. Bull. 85, 747-753.

Ma, X., Cogswell, A., Li, Z., Lee, K., 2008. Particle size analysis of dispersed oil and oil-mineral aggregates with an automated ultraviolet epi-fluorescence microscopy system. Environ. Technol. 29, 739-748.

Moreira, I.T.A., 2014. Investigação dos Possíveis Impactos Ecológicos do Petróleo Sobre Comunidades Biológicas Estuarinas na Baía de Todos os Santos e no sul da Bahia: 
OSA como uma Ferramenta Norteadora Tese (Doutorado em Geologia Ambiental, Hidrologia e dos Recursos Hídricos) Instituto de Geociências, Universidade Federal da Bahia.

Moreira, I.T.A., Oliveira, O.M.C., Triguis, J.A., Queiroz, A.F.S., Ferreira, S.L.C., Martins, C.M.S. Silva, A.C.M., Falcão, B.A., 2013. Phytoremediation in mangrove sediments impacted by persistent total petroleum hydrocarbons (TPH's) using Avicennia schaueriana. Mar. Pollut. Bull. 67, 130-136.

Moreira, I.T.A., Oliveira, O.M.C., Silva, C.S., Rios, M.C. Queiroz, A.F.S., Assunção, R.V. Carvalho, A.P.N., 2015. Chemometrics applied in laboratory study on formation of oil-spm aggregates (OSA) - a contribution to ecological evaluation. Microchem. J. $118,198-202$

Muschenheim, D.K., Lee, K., 2002. Removal of oil from the sea surface through particulate interactions: review and prospectus. Spill Sci. Technol. Bull. 8, 9-18.

Nemr, A.E., Khaled, A., El-Sikaily, A., Said, T.O., Abd-Allah, A.M.A., 2005. Distribution and sources of polycyclic aromatic hydrocarbons in surface sediments of the Suez gulf. Environ. Monit. Assess. 111, 333-358.

Odum, W.E., Heald, E.J., 1972. Trophic analysis of an estuarine mangrove community. Bull. Mar. Sci. 22, 671-738

Omotoso, O.E., Munoz, V.A., Mikula, R.J., 2002. Mechanisms of crude oil-mineral interac tions. Spill Sci. Technol. Bull. 8, 45-54

Owens, E.H., Lee, K., 2003. Interaction of oil and mineral fines on shorelines: review and assessment. Mar. Pollut. Bull. 47, 397-405.

Paladino, O., Massabò, M., Fissore, F., Moranda, A., 2015. Assessment of sediment contamination and sampling design in Savona harbour, Italy. Mar. Pollut. Bull. 91, 54-64.

Pekey, H., 2006. The distribution and sources of heavy metals in Izmit Bay surface sediments affected by a polluted stream. Mar. Pollut Bull. 52 1197-1208.

Pereira, T.S., Moreira, I.T.A., Oliveira, O.M.C., Rios, M.C., Filho, W.A.C.S., Almeida, M., Carvalho, G.C., 2015. Distribution and ecotoxicology of bioavailable metals and As in surface sediments of Paraguaçu estuary, Todos os Santos Bay, Brazil. Mar. Pollut. Bull.

Pletsch, M., Charlwood, B.V., Araújo, B.S., 2004. Fitorremediação de água e solos poluídos. Biotecnolog. Ciênc. Desenvolv 34, 26-29.

Rios, M.C., 2014. Capacidade do Estuário do Paraguaçu-BA de Formar Agregado Óleo-material Particulado em Suspensão (OSA) (Monografia (Graduação em Oceanografia)) Instituto de Geociência, Universidade Federal da Bahia.

Salles, R.P., 2010. A Sedimentação no Canal do Paraguaçu (Monografia (Graduação em Oceanografia)) Instituto de Geociências, Universidade Federal da Bahia.

Santos, D.R., 2010. Investigação da Interação Óleo-mineral Agregado (OMA) em Ambientes Costeiros sob Influência de Diferentes Salinidades: Subsídio a Procedimentos de Remediação de Derrames de Petróleo (Monografia (Graduação em Geologia)) Instituto de Geociência, Universidade Federal da Bahia.

Schön, J.H., 1996. In: Helbig, K., Treitel, S. (Eds.), Physical Properties of Rocks: Fundamentals and Principles of Petrophysics. Handbook of Geophysical Exploration: Seismic Exploration 18, Chapter 3600 .

Silva, C.S., 2014. Potencial do OSA (Agregado Óleo-material Particulado em Suspensão) como agente de Remedição em Modelos de Simulação de Praias Impactadas por Petróleo (Dissertação (Mestrado em Geociências)) Instituto de Geociências, Universidade Federal da Bahia.

Silva, C.S., Oliveira, O.M.C., Moreira, I.T.A., Queiroz, A.F.S., Almeida, A., Silva, J.V.L., Andrade, I.O.S., 2015. Potential application of oil-suspended particulate matter aggregates (OSA) on the remediation of reflective beaches impacted by petroleum: a mesocosm simulation. Environ. Sci. Pollut. Res. 1-13.

Soares-Gomes, A., Neves, R.L., Aucélio, R., Van Der Ven, P.H., Pitombo, F.B., Mendes, C.L.T. Ziolli, R.L., 2010. Changes and variations of polycyclic aromatic hydrocarbon concentrations in fish, barnacles and crabs following an oil spill in a mangrove of Guanabara Bay, Southeast Brazil. Mar. Pollut. Bull. 60, 1359-1363.
Sørensen, L., Melbye, A.G, Booth, A.M. 2013. Oil droplet interaction with suspended sediment in the seawater column: influence of physical parameters and chemical dispersants. Mar. Pollut. Bull. 78 (1-2), 146-152.

Souza, I.S., Araujo, G.S., Cruz, A.C.F., Fonseca, T.G., Camargo, J.B.D.A., Medeiros, G.F., Abessa, D.M.S., 2016. Using an integrated approach to assess the sediment quality of an estuary from the semi-arid coast of Brazil. Mar. Pollut. Bull. 104, 70-82.

STATSOFT Inc., 2009. STATISTICA for the Windows Operating System. Release 9. StatSoft, Tulsa: EUA.

Sterling Jr., M.C., Bonner, J.S., Ernest, A.N.S., Page, C.A., Autenrieth, R.L., 2004 Characterizing aquatic sediment-oil aggregates using in situ instruments. Mar. Pollut. Bull. 48, 533-542.

Stoffyn-Egli, P., Lee, K., 2002. Formation and characterization of oil-mineral aggregates. Spill Sci. Technol. Bull. 8, 31-44.

Sun, J., Zheng, A.X., 2009. A review of oil-suspended particulate matter aggregation - a natural process of cleansing spilled oil in the aquatic environment. J. Environ. Monit. 11, 1801-1809.

Sun, J., Khelifa, A., Zheng, A.X., Wang, Z., So, L.L., Wong, S., Yang, C., Fieldhouse, B., 2010. A laboratory study on the kinetics of the formation of oil-suspended particulate matter aggregates using the NIST-1941b sediment. Mar. Pollut. Bull. 60, 1701-1707.

Szewczyk, S.B.O., 2006. Processos envolvidos em um derramamento de óleo no mar. Seminário e Workshop em Engenharia Oceânica (SEMENGO).

Tam, N.F.Y., Wong, Y.S., Lan, C.Y., Wang, L.N., 1998. Litter production and decomposition in a subtropical mangrove swamp receiving wastewater. J. Exp. Mar. Biol. Ecol. 226, $1-18$.

Tansel, B., Arreaza, A., Tansel, D.Z., Lee, M., 2015. Decrease in osmotically driven water flux and transport through mangrove roots after oil spills in the presence and absence of dispersants. Mar. Pollut. Bull. 98, 34-39.

Trindade, M.C.L.F., 2011. Formação e Caracterização de Agregados Óleo-mineral em Diferentes Energias Hidrodinâmicas (Monografia (Graduação em Oceanografia)) Instituto de Geociências, Universidade Federal da Bahia.

Vannucci, M., 2002. Os Manguezais e nós: uma Síntese de Percepções. 2nd ed. Editora da Universidade de São Paulo, São Paulo.

Veiga, I.G., 2003. Avaliação da origem dos hidrocarbonetos em sedimentos superficiais de manguezais da região norte da Baía de Todos os Santos, Bahia (Dissertação (Mestrado em Engenharia e Exploração de Petróleo)) Universidade Estadual Norte Fluminense.

Vidali, M., 2001. Bioremediation: an overview. J. Appl. Chem. 73, 1163-1172.

Wang, Z., Yang, C., Fingas, M., Hollebone, B., Yim, U.H., Oh, J.R., 2007. Petroleum biomarker fingerprinting for oil spill characterization and source identification. Oil Spill Environmental Forensics: Fingerprinting and Source Identification. 7, pp. 74-146.

Wang, Y., Zhu, H., Tam, N.F.Y., 2014. Effect of a polybrominated diphenyl ether congener (BDE-47) on growth and antioxidative enzymes of two mangrove plant species, Kandelia obovata and Avicennia marina, in South China. Mar. Pollut. Bull. 85, 376-384.

Weise, A.M., Nalewajko, C., Lee, K., 1999. Oil-mineral fine interactions facilitate oil biodegradation in seawater. Environ. Technol. 20, 811-824.

Wincele, D.E., Wrenn, B.A., Venosa, A.D., 2004. Sedimentation of oil-mineral aggregates for remediation of vegetable oil spills. J. Environ. Eng. 130, 50-58.

Yang, X., Yuan, X., Zhang, A., Mao, Y., Li, Q., Zong, H., Wang, L., Li, X., 2015. Spatial distribution and sources of heavy metals and petroleum hydrocarbon in the sand flats of Shuangtaizi Estuary, Bohai Sea of China. Mar. Pollut. Bull. 95, 503-512.

Zhao, L., Boufadel, M.C., Geng, X., Lee, K., King, T., Robinson, B., Fitzpatrick, F., 2016. ADROP: A predictive model for the formation of oil particle aggregates (OPAs). Mar. Pollut. Bull. 106 (1-2), 245-259. 